\title{
PENGEMBANGAN KAPASITAS KELEMBAGAAN KELOMPOK TANI SEBAGAI PILAR PEMBERDAYAAN PETANI
}

\author{
Dwi Wahyu Prasetyono \\ Universitas Wijaya Putra \\ dwiwahyu@uwp.ac.id
}

\begin{abstract}
Abstrak
Program ini betrtujuan untuk meningkatkan kapasitas para petani dalam menyelesaikan masalah dan meningkatkan produktivitasnya. Karenanya diberikan pemberdayaan yang berpijak pada paradigma pembangunan yang berpusat pada manusia (masyarakat). Pemberdayaan diberikan dalam pendekatan kolektif melalui pengembangan kapasitas kelembagaan kelompok tani, serta dengan menekankan proses secara bottom-up dan pelibatan partisipasi sasaran. Dalam pengembangan kapasitas kelembagaan kelompok tani, mencakup pada dua aspek, yaitu pengembangan sumber-daya manusia (SDM) dan kepemimpinan dalam organisasi kelompok tani. Perubahan dalam kepemimpinan dan makin meningkatnya partisipasi mendorong terjadinya perubahan dalam kelembagaan poktan. Keterlibatan partisipasi dalam pengembangan kapasitas dalam pemberdayaan merupakan stimuli adanya pertukaran dan distribusi pengetahuan, yang merupakan proses konstruksi sosial dalam membentuk pengetahuan kolektif petani. Tumbuhnya ruang publik, mendorong terjadinya mobilisasi dan akumulasi sumberdaya, serta munculnya agen-agen baru diantara anggota poktan yang dapat mendukung pengembangan jejaring dan kemungkinan keberlanjutan pemberdayaan secara mandiri. Secara menyeluruh pemberdayaan membentuk kekuatan kolektif petani yang tergabung dalam kelompok tani, sebagai akumulasi kekuatan individu di dalamnya. Mulai terbentuknya kemampuan dan kemandirian dalam mengambil keputusan kolektif poktan, dalam menyelesaikan masalah dan penentuan produksi dan budidaya merupakan salah satu kekuatan dampak dari pengembangkan kapasitas kelembagaan kelompok tani.
\end{abstract}

Kata Kunci : Pengembangan Kapasitas; Kelompok Tani; Pemberdayaan

\section{PENDAHULUAN}

Pemberdayaan merupakan salah satu pespektif dari berbagai perspektif tentang pembangunan masyarakat (Prasojo, 2003), yang munculnya berangkat dari kebutuhan pembangunan manusia dan berpijak pada paradigma pembangunan berpusat pada manusia atau masyarakat, yang menekankan manusia dan masyarakat sebagi subyeknya (Wrihatnolo dan Dwidjowijoto, 2007; Maani, 2011). Paradigma pembangunan yang berpusat pada manusia disebut Wardhani (2009) sebagai elemen dasar dari strategi pembangunan yang lebih luas, yang tujuannya untuk mencapai suatu transformasi berdasarkan nilai-nilai yang berpusat pada manusia dan potensi-potensi yang ditawarkan oleh teknologi maju. Sebagai sebuah konsep holistik, paradigma pembangunan berpusat pada manusia mengandung empat unsur penting, yakni: (1) peningkatan produktivitas; (2) pemerataan kesempatan; (3) kesinambungan pembangunan; serta (4) pemberdayaan manusia (Kartasasmita, 1997). Dalam gagasan kontemporer, pemberdayaan sering dihubungkan dengan praktek kerja sosial (pengabdian masyarakat), dalam rangka membantu suatu pihak yang anggap tidak berdaya (McLaughlin 2016; Albuquerque et al., 2017)

$$
\text { Ekonomi, Sosial, dan Budaya }
$$


Bahasan dalam kajian ini, merupakan bagian dari hasil kegiatan pengabdian kepada masyarakat Program Pengembangan Desa Mitra (PPDM) Mewujudkan Desa Mojogede Menuju Desa Sentra Organic Farming. Desa Mojogede merupakan salah satu desa di Kecamatan Balongpanggang Gresik, yang memiliki keluarga miskin cukup tinggi. Dari data Pemerintah Desa Mojogede (2017), jumlah keluarga di desa Mojogede ada 619 keluarga, dan sebanyak 200 keluarga diantaranya termasuk kategori miskin. Jumlah keseluruhan penduduk adalah 2.026 jiwa (1.019 jiwa lak-laki dan 1.007 jiwa perempuan), demham 1.200 jiwa diantaranya bekerja sebagai petani, dan 500 jiwa sebagai buruh tani. Selain latar besarnya penduduk dengan profesi buruh tani, rendahnya produktivitas pertanian desa Mojogede memberikan sumbangan yang signifikan atas rendahnya pendapatan dan kemiskinan yang ada. Dari 177,5 Ha luas lahan pertanian di Desa Mojogede, sebanyak 147,5 Ha $(83,1 \%)$ diantaranya adalah lahan sawah tadah hujan, dan selebihnya 30 Ha merupakan lahan sawah $1 / 2$ teknis.

Belum berkembang inovasi dan penerapan teknologi tepat guna (TTG) dalam pertanian desa, sejalan dengan yang dikemukanan Adamson (2010) bahwa hambatannya selain lemahnya kapasitas individu anggota masyarakat, juga karena lemahnya kapasitas organisasi atau kelembagaan yang ada dalam masyarakat. Lemahnya kapasitas organisasi kelompok tani di desa Mojogede menjadikan tidak peka terhadap permasalahan dan kebutuhan anggota kelompok tani. Kelompok tani belum mampu sepenuhnya menjadi ruang publik, yang memberikan ruang kepada petani untuk saling berinteraksi menyuarakan permasalahan bersama. Pada gilirannya partisipasi anggota kelompok tani dalam perumusan dan pengambilan keputusan organisasi rendah. Tujuan dari program PPDM ini adalah untuk: (1) menumbuh-kembangkan kapasitas kelembagaan kelompok tani desa Mojogede dalam mengelola dan menyelesaikan masalah yang dihadapi dengan mengoptimalkan pemanfaatan segala potensi di desanya; (2) mengembangkan kapasitas penguasaan dan penerapan TTG guna membantu pengolahan potensi sumberdaya desa untuk mendukung peningkatan produktivitas masyarakat desa; (3) meningkatkan kualitas budidaya dan produktivitas pertanian yang mengarah pada pertanian organik dan komoditas produk unggulan desa.

\section{KERANGKA KONSEPTUAL}

Konseptualisasi kerangka pikir yang dibangun dalam program PPDM ini adalah bahwa untuk mewujudkan tujuan tersebut diperlukan pemberdayaan kepada para petani. Pemberdayaan apapun pada dasarnya akan menyangkut pada suatu keinginan untuk membantu atau mendorong pihak yang diberdayakan untuk dapat mengembangkan kepercayaan, kompetensi dan harga diri agar yang bersangkutan memiliki nilai lebih (McLaughlin, 2016: 64 ). Pemberdayaan akan berhubungan dengan upaya pemeliharaan tata kehidupan sosial untuk mengurangi kerentanan dan meningkatkan kekuatan atau kemampuan baik pada tingkat individu dan kelompok agar mampu membuat pilihan dan mentransformasikannya (Albuquerque et al., 2017), dan pada prinsipnya merupakan upaya untuk meningkatkan martabat masyarakat agar mampu mandiri (Hadiyanti, 2016).

Intervensi pemberdayaan yang diberikan dipilih dalam pendekatan kolektif, dalam hal ini melalui kelompok tani mitra. Dalam pandangan konstruktivisme, pemberdayaan merupakan konstruksi berkelanjutan dari pelibatan partisipasi yang multi-dimensi yang mencakup pada upaya mengarahkan terjadinya perubahan kognitif dan perilaku pada kelompok sasaran (Fitzgerald, 2011). Dalam perspektif itu, pemberdayaan adalah upaya mendorong meningkatnya derajat pengetahuan kelompok sasaran. Pemberdayaan dalam perspektif konstruktivisme menekankan bahwa pengetahuan tidaklah diberikan, tetapi dibangun secara pribadi, dimana konstruksi pengetahuan harus dikembangkan dalam konteks sosial masyarakat dan melibatkan kolaborasi (Fitzgerald, 2011). Pemberdayaan kolektif memerlukan adanya partisipasipatory, yang memungkinkan tumbuhnya kolaborasi, yang mengarah pada pertukaran informasi dan distribudi pengetahuan diantara pada individu di dalamnya (Hannon, 2019). Konstruksi pengetahuan merupakan bentuk proses pembelajaran dalam masyarakat yang terbentuk pada proses interaksi sosial. Dengan demikian konstruksi pengetahuan dapat dipahami sebagai konstruksi sosial dalam masyarakat dalam

$$
\text { Ekonomi, Sosial, dan Budaya }
$$

1286 
membetuk pemahaman atas keberadaannya. Pemberdayaan mendorong terjadinya pembelajaran secara bottom up yang dibangun atas dasar dan melibatkan partisipasi anggota organisasi dan anggota masyarkat.

Kesesuaian pendekatan pemberdayaan kolektif dalam program ini, sebagaimana dikemukakan Alkire et al. (2013) yang menjelaskan bahwa domain dari pemberdayaan untuk petani meliputi aspek: (1) produksi, menyangkut pada keputusan bersama atas produk pertanian yang akan dibudidayakan dan dihasilkan; (2) sumberdaya, yang tidak hanya pada sisi kepemilikan, namun termasuk pula dalam hal akses terhadap sumberdaya dan kekuatan pengambilan keputusan dalam kaitan pemanfaatan sumberdaya produktif; (3) pendapatan, yang menyangkut pada kemampuan untuk mengatur dan mengendalikan pemanfaatan pendapatannya; (4) kepemipinan, menyangkut pada hubungan dengan anggota, dan adanya kenyamanan anggota untuk menyampaikan aspirasi dalam kelembagaan petani; dan (5) waktu, yaitu menyangkut pada kemampuan dalam pemanfaatan dan alokasi waktu untuk bekerja dan beristirahat. Ke lima domain tersebut mensiratkan keberadaan petani dalam suatu kelembagaan sosial dan hubungannya dengan pihak lain dalam kontek akses sumberdaya. Dalam pemberdayaan masyarakat petani pedesaan, salah satu strateginya adalah dengan pengembangan kelembagaan masyarakat, yang dapat ditempuh dengan dan atau melalui pengembangan jejaring (Zamhariri, 2008).

Pengembangan kapasitas, dalam pemberdayaan, merupakan proses transfer kompetensi yang diperlukan kepada suatu kelompok masyarakat atau individu (di dalamnya) sebagai upaya untuk mengidentifikasi dan menyelesaikan masalah mereka (Suarez-Balcazar, Balcazar, TaylorRitzler, \& Iriarte, 2008). Organisasi dan kelembagaan (sosial) masyarakat merupakan wadah dan media pergerakan bagi anggota masyarakat untuk melakukan perubahan sosial dalam membangun dan mengembangkan derajat kehidupannya. Hingga keberadaannya merupakan representasi dari keberadaan masyarakat yang bersangkutan serta mencerminkan kapasitas dan kapabilitas masyarakat dan anggotanya. Dengan demikian maka pengembangan kapasitas pada tingkat organisasi diarahkan untuk membangun kemampuan organisasi masyarakat yang bersangkuta agar memiliki kapabilitas dan kapasitas yang memadai dalam mendukung pengembangan masyarakat (Aref, Redzuan, \& Gill, 2010). Pada sisi lain, penekanan pengembangan kapasitas secara kolektif pada tingkat kelembagaan atau organisasi, karena melalui kelembagaan masyarakat akan terjadi upaya membangun dan mengembangkan kapasitas anggota, yang melibatkan dan untuk partisipatori anggota (Adamson \& Bromiley, 2013).

Dalam pemberdayaan kolektif mencakup empat elemen (Reininger et al., 2006), di mana pengembangan kapasitas merupakan elemen dasar yang menjadi pijakan yang mengawali dan mendasari kegiatan pemberdayaan lebih lanjut, yang arahnya menjadikan kelompok sasaran memiliki kontrol atas keputusan, dan adanya perbaikan kehidupannya. Ke empat elemen pembedayaan kolektif tersebut meliputi: (1) kontrol dan perbaikan kehidupan masyarakat secara agregat, merupakan tujuan yang ingin dicapai; (2) Kemampuan mendefinisikan masalah, pemetaan aset, perumusan solusi masalah, proses dan arah perubahan sosial, merupakan kondisi yang menjadi prasyarat untuk mencapai tujuan; (3) kekuatan dan pengetahuan lembaga masyarakat, merupakan kapasitas yang harus ada dan merupakan prasyarat untuk mewujudkan elemen ke dua; dan (4) pengembangan kapasitas individu dan kolektif dalam masyarakat, merupakan proses intervensi dalam pemberdayaan sebagai pijakan untuk menumbuhkan elemen ke tiga (Reininger et al., 2006).

\section{METODE}

Program pengabdian masyarakat (pekerjaan sosial) pada dasarnya adalah untuk memperkaya masyarakat melalui orientasi dan pemberdayaan individu dan masyarakat menuju perubahan sosial dan pola hidup baru (Şahİn, 2016). Kontek pemberdayaan dalam program ini dipilih pendekatan pada pemberdayaan masyarakat secara kolektif, karena pemberdayaan (sebagai proses) dan keberdayaan (sebagai hasilnya) akan merujuk pada kemampuan individu-individu manusia yang bersenyawa dalam masyarakat dan membangun keberdayaan masyarakat yang bersangkutan Ekonomi, Sosial, dan Budaya

1287 
(Wrihatnolo \& Dwidjowijoto, 2007: 75). Pendekatan kolektif dalam pemberdayaan masyarakat dapat dapat ditempuh melalui organisasi atau kelembagaan dalam masyarakat (Prasetyono et al, 2017) yang dalam hal ini melalui organisasi kelompok tani yang ada di Desa Mojogede. Pengembangan kapasitas secara kolektif pada tingkat masyarakat dan organisasi, dalam prakteknya berupaya untuk fokus pada hubungan antara warga masyarakat, kelompok lokal dan organisasi masyarakat setempat untuk membangun pengembangan masyarakat (Aref et al., 2010). Dalam pemberdaayaan secara kolektif melalui kelembagaan kelompok tani (poktan) akan menggunakan tiga jalur pendekatan dari Albuquerque (et al., 2017), yaitu: (1) pengembangan kesadaran kolektif, dimana permasalahan yang dihadapi para petani bukan hanya persolahan individu diantara mereka; (2) pengembangan kesadaran sosial, dengan menumbuhkan pemahaman bahwa permasalahan individu dan sosial para petani kususnya dan masyarakat pada umumnya dipengaruhi oleh organisasi sosial dalam masyarakatnya termasuk organisasi poktan; dan (3) pengembangan kesadaran untuk melakukan pergerakan perubahan sosial, karena penyelesaian masalah membutuhkan adanya perubahan sosial.

Pengembangan kapasitas yang diberikan dalam program pemberdayaan ini mencakup pada dua aspek, yaitu pada penguasaan dan penerapan TTG, serta pengembangan kapasitas organisasi kelompok tani. Intervensi yang diberikan dalam pengembangan kapasitas penguasaan dan penerapan TTG, merujuk Sianipar (et al., 2013) yakni mencakup pada: (1) stimuli dengan memberikan fasilitas dan peralatan; (2) mengajari cara menggunakan dan merawat dengan metode yang lebih baik; (3) mengajari cara membuat sendiri; dan (4) mengajari dalam cara menyesuaikan fungsi berdasar kondisi yang dipersyaratkan. Mengikuti Aref (et al., 2010) intervensi dalam pengembangan kapasitas organisasi masyarakat mencakup pada pengembangan sumber daya manusia (SDM) dan kepemimpinan dalam organisasi masyarakat. Pada perspektif kepemimpinan, bahwa pemberdayaan akan menyangkut pada bagaimana pemimpin dapat melakukan distribusi atau pembagian kekuasaan dan tanggungjawab dengan para pengikutnya, karena dengan gaya kepemimpinan yang demikian akat menumbuhkan adaya partisipasi dalam pengambilan keputusan dan kepercayaan diri (Al-Madadha, 2014). Visualisasi model dan proses intervensi pemberdayaan dalam program ini sebagaimana gambar 1.

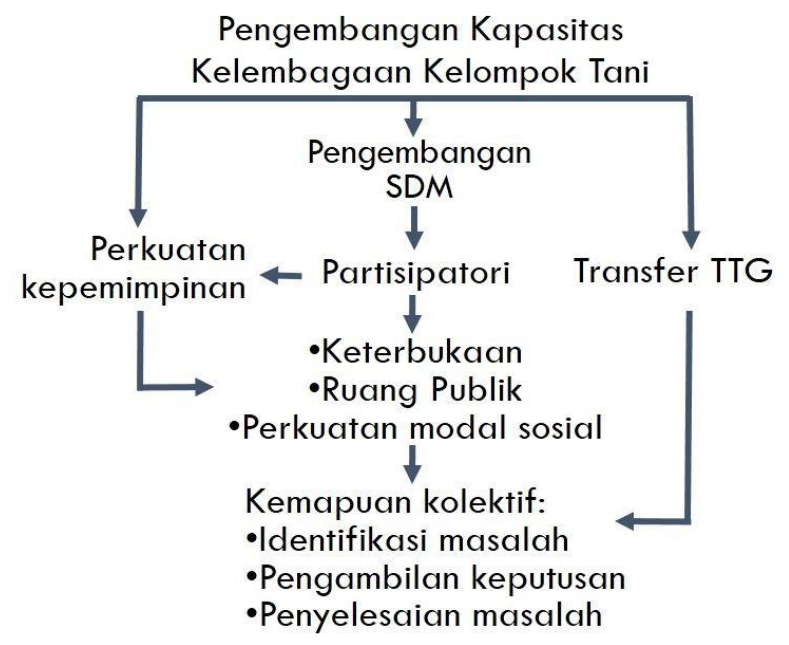

Gambar 1: Kerangka intervesi program

\section{CAPAIAN HASIL}

\section{Stimuli Fasilitas dan Peralatan}

Bahwa setiap manusia dalam beraktivitas akan mempertimbangan apa yang didapat dari keterlibatannya dalan suatu kegiatan. Karena itu diberikan bantuan fasilitas dan peralatan yang dimaksudkan sebagai stimuli untuk menggugah kesadaran dan kesediaan para petani kelompok sasaran agar berpatisipasi dalam pelaksanaan pemberdayaan. Fasilitas dan peralatan yang diberikan merupakan sarana dalam penyelesaian peramasalahan yang dihadapi mitra. Bantuan fasilitas dan peralatan yang diberikan kepada mitra diantaranya adalah: (1) pembuatan sumur bor; (2) mesin pompa air; (3) alat tanam benih polowijol dan (4) mesin pencacah kompos.

Lahan pertanian desa yang merupakan lahan tadah hujan, menjadikan budidaya efektif hanya pada musim penghujan. Selama musim kemarau terjadi kekeringan, kesulitan air bukan hanya untuk kebutuhan pengairan lahan namun juga untuk keperluan sehari-hari. Keberadaan sumur bor sangat

$$
\text { Ekonomi, Sosial, dan Budaya }
$$


membantu dalam penyediaan air pada musim kemarau, baik kebutuhan hidup sehari-hari juga membantu pada sebagian lahan pertanian dalam budidaya polowijo. Mesin pompa air, sangat membantu para petani dalam distribusi irigasi terutama pada lahan yang lentak konturnya lebih tinggi dari permukaan saluran irigasi. Dengan diberikannya alat tanam benih, memberikan keuntungan pada petani pada percepatan proses tanam benih komoditas polowijo.

\section{Penerapan TTG}

Dalam mengatasi keterbatasan sumberdaya diperlukan kemampuan untuk mengembangkan ideide kreatif dikalangan petani guna melakukan inovasi. Penerapan TTG merupakan salah satu sarana dalam melakukan inovasi dalam mengelola dan memanfaatkan berbagai potensi agar memiliki nilai lebih. Penerapan TTG yang diberikan mencakup pada: (1) pembuatan pupuk organik padat (POD) dari pengolahan limbah kompos dari lahan pertanian (dengan didukung peralatan yang diberikan); dan (2) pengembangan intensifikasi budidaya komoditas. Berkait dengan penerapan TTG, pelatihan yang diberikan kepada mitra: pertama, adalah pelatihan dalam memanfaatkan peralatan dan pembuatan POD. Dengan adanya kapabilitas dalam memanfaatkan dan mengolah limbah organik lahan, diharapkan ke depan para petani dapat membuat POD sendiri, yang nantinya dapat membantu mengurangi beban pengadaan pupuk serta mendukung konversi budidaya komoditas pertanian dari konvensional ke pertanian organik. Kedua, adalah pelatihan pembenihan dan budiadaya komoditas, dan pembuatan demplot untuk pembenihan. Hasil dari pelatihan ini, adalah: (1) mucul diversifikasi komoditas yang dibudidayakan, sebagai alternatif tambahan potensi produk yang memungkinkan minat pasar memberikan pengahasilan; (2) adanya peningkatan kapabilitas budidaya yang menjadikan adanya parbaikan kualitas dan kuantitas produk.

Peningkatan kapabilitas petani dalam penguasaan dan penerapan TTG, menumbuhkan peningkatkan kapasitas petani secara kolektif dalam kelompok tani, dalam menyelesaikan sebagian permasalahan yang dihadapi. Penguasaan dan pemanfaatan TTG dapat dipandang sebagai salah satu tahap penting untuk menumbuhkan kemampuan kemandirian kelompok tani. Kondisi demikian cukup memberikan harapan akan adanya kemungkinan untuk keberlanjutan pemberdayaan para petani secara mandiri melalui kelembagaan organisasi poktan.

\section{Pengembangan Kapasitas Kelembagaan Poktan}

Pengembangan kapasitas kelembagaan poktan mencakup pada dua aspek, yaitu pengembangan SDM dan kepemipinan dalam organisasi. Pengembangan SDM meliputi pada penguasaan dan penerapan TTG, serta pada pengembangan kesadaran, motivasi dan kapasitas pengembangan diri. Pengembangan SDM pada penguasan dan penerapan TTG, dilakukan dengan memberikan stimuli bantuan dan pelatihan sebagaimana dijelaskan pada bahasan sebelumnya. Pengembangan kesadaran, motivasi dan kapasitas pengembangan diri anggota poktan dan pengembangan kepemipinan organisasi poktan, dilakukan melalui model pendampingan dan focus group discussion (FGD) sesuai kebutuhan dan tingkatan masing-masing. Secara kolektif, terjadi peningkatan kemauan petani untuk berkembang dan makin memberdayakan diri-sendiri. Hal itu tercermin dari mulai berkembangnya berbagai pertemuan anggota poktan yang membicarakan berbagai permasalahan yang dihadapi dan usulan penyelesaiannya, serta kemungkinan usulan dalam pengembangan program bersama dalam budidaya dan penentuan komoditas yang akan dibudidayakan.

Pada sisi kepemimpinan organisasi poktan, berkembang interaksi dan keterbukaan antara ketua dengan anggota. Kepemimpinan dalam organisasi poktan yang semakin membuka ruang partisipasi anggota, dan meningkatnya jumlah anggota yang terlibat dalam aktivitas kegiatan poktan. Kapabilitas kepemimpian organisasi telah dapat mendorong dan membuka terciptanya ruang-ruang publik berupa forum-forum diskusi yang melibatkan para anggota. Partisipatory anggota dalan aktivitas organisasi poktan, pada muaranya juga membuka kesadaran dan kemauan anggota untuk membatu dalam membangun jejaring kerjasama. Dengan demikian, mulai berkembang jejaring kerjasama antar poktan,

$$
\text { Ekonomi, Sosial, dan Budaya }
$$


jejaring dengan berbagai pihak lainnya yang memiliki keterkaitan dengan aktivitas, keperluan dan penyelesaian masalah bersama. Perubahan dalam kapasitas kepemimpinan, dan ditopang dengan terbukanya ruang partisipasi, semakin memperkuat kebersamaan dan pemahaman akan kebutuhan dan arti penting penyelesaian masalah bersama. Potensi dan kekuatan dalam produksi dan penyelesaian permasalahan bersama, disadari akan tumbuh dalam kebersamaan. Kekuatan kelompok merupakan akumulasi dari kekuatan anggota secara agregat.

Berkembangnya kapasitas kelembagaan dalam organisasi poktan, baik dalam kemampuan SDM dan partisipasinya, serta kapasitas kepemimpinan, menjadikan semakin berkurangnya ketergantungan poktan pada pimpinan desa dan pemerintah desa dalam pembinaan anggotanya. Mulai tumbuh kemampuan untuk membuat keputusan dalam pengembangan kegiatan dan pengembangan budidaya, dengan tidak meninggalkan koordinasi dan sinkronisasi dengan program pemerintah desa. Dengan berkembangnya kapasitas poktan, pada satu sisi dapat mempermudah pemerintah desa, karena poktan menjadi lebih mampu untuk menyelesaikan permasalahannya sendiri.

\section{PEMBAHASAN}

Intervensi pemberdayaan program ini dilakukan melalui pendekatan persuasif dan model pendampingan, diarahkan untuk membangun adanya saling kepercayaan antara pelaksana program dengan kelompok sasaran dan diantara kelompok sasaran, sehingga terjadi interaksi positif dalam upaya menyelesaikan masalah (Şahİn, 2016). Intervensi dalam pemberdayaan, mulai dari pemberian stimuli bantuan peralatan, pelatihan dan pendampingan, merupakan upaya yang diarahakan agar terjadi perubahan yang bisa dirasakan oleh anggota poktan sejak pada fase awal intervensi. Hal itu sangat penting untuk memastikan adanya perubahan yang secara langsung dapat dirasakan oleh petani anggota poktan sebagai kelompok sasaran, merupakan hasil dari partisipasinya (Adamson \& Bromiley, 2013).

Pelibatan partisipasi para anggota poktan dalam semua kegiatan meningkatkan intensitas interaksi sosial antar anggota poktan di luar aktivitas pekerjaan, memiliki beberapa keuntungan, diantaranya: (1) membantu meningkatan kesadaran kolektif akan perlunya melakukan perubahan secara kolektif dalam penyelesaian masalah (Albuquerque et al., 2017); dan (2) terjadi adanya pertukaran informasi dan distribudi pengetahuan diantara pada individu di dalamnya (Hannon, 2019), menjadikan semakin meratanya dalam kapabilitas penguasaan TTG, serta pemahaman akan permasalahan bersama dan penyelesaiannya. Pertukaran informasi dan distribusi pengetahuan merupakan mekanisme konstruksi sosial dalam membentuk pengetahuan mereka (Şahİn, 2016), melalui interaksi antar anggota poktan, baik dalam partisipasinya pada kegiatan pemberdayaan maupun pada ruang publik yang mereka ciptakan. Partisipasi dalam pemberdayaan merupakan prinsip penting untuk adanya perubahan. Peran penting konstruksi sosial dalam pemberdayaan dan pengabdian masyarakat pada umumnya adalah bahwa pendekatan konstruksi sosial menstimuli dan memungkinkan untuk tumbuh-kembangnya partisipasi dalam pemberdayaan (Şahİn, 2016).

Pemberdayaan petani dalam pendekatan kolektif melalaui kelembagaan poktan, selain meningkatakan kapasitas perorangan anggota poktan, juga mendorong terjadinya perubahan dalam kepemimpinan poktan. Meningkatnya kapasitas kelembagaan poktan pada satu sisi dapat menumbuhkan revitalisasi fungsi dan peran organisasi poktan sekaligus memperkuat akumulasi kekuatan sosial yang diperlukan untuk pijakan pemberdayaan (Prasetyono et al., 2017). Keterlibatan partisipasi anggota poktan, dan ditopang makin meningkatnya kapasitas kepemimpian organisasi poktan, mendorong tumbuh-kembangnya ruang publik di masyarakat sebagai salah satu media interaksi sosial. Kondisi demikian mampu mendorong keberanian anggota poktan untuk tampil menjadi agen perubahan dan memanfaatkan jejaring pribadinya untuk membantu pengembangan keberdayaan para petani anggota poktan. Dengan demikian pemberdayaan kolektif kepada para petani melalui kelembagaan organisasi poktan mampu mendorong munculnya agen-agen yang menjadi penghubung antara pihak yang memberi pemberdayaan dengan anggota masyarakat kelompok sasaran (Hannon, 2019).

$$
\text { Ekonomi, Sosial, dan Budaya }
$$


Pengembangan kapasitas yang dilaksanakan dalam program pemberdayaan kepada petani dalam program ini, dengan memperkuat SDM pada tingkat individu anggota poktan, menumbuh-kembangkan kepemimpinan poktan yang lebih baik, telah mendorong terjadinya mobilisasi sumberdaya dalam komunitas petani yang kemudian menumbuhkan kekuatan pada komunitas petani itu sendiri (Aref et al., 2010), yang ditandai dengan berkembangnya kemampuan poktan dalam mengambil keputusan dalam penyelesaian masalahnya. Pelibatan partisipasi dalam program pemberdayaan dan pengembangan kepemimpinan poktan, mendorong terjadinya mobilisasi sumberdaya pengembangan jejaring sosial, merupakan pengembangan kekuatan dalam komunitas petani, merupakan dimensi penting dalam kapasitas kelembagaan yang mewakili modal sosial komunitas petani (Aref et al., 2010). Modal sosial dan pemberdayaan merupakan konsep yang saling berkaitan, yang yang mana keduanya dihasilkan secara bersama dari hubungan antar individu dalam masyarakat (Bagley \& Ackerley, 2006). Pemberdayaan kolektif akan menghasilkan hubungan kerjasama antar individu yang kemudian mampu membentuk perilaku kolektif (modal sosial) yang kemudian akan mendukung terjadinya keberlanjutan pemberdayaan. Dalam pelaksanaan pemberdayaan lebih lanjut, modal sosial dapat dipakai untuk mengidentifikasi kebutuhan, membuat perencanaan dan implementasi program pemberdayaan secara bottom-up (Bagley \& Ackerley, 2006).

Tumbuh-kembangnya kapasitas potan dalam membuat keputusan dan mengupayakan penyelesaian masalah secara lebih mandiri, sejalan dengan konsep Zamhariri (2008) bahwa pemberdayaan lebih menekankan pada otonomi dalam pengambilan keputusan dari suatu kelompok masyarakat. Adanya perubahan dalam kelembagaan poktan, seberapapun kadarnya, merupakan bentuk perubahan sosial dari dampak pemberdayaan melalui pengembangan kapasitas (Suarez-Balcazar et al., 2008). Melalui jejaring sosial yang dimiliki poktan, diharapkan ke depan pengembangan kapasitas pada tingkat organisasi poktan dapat mendorong dalam pemngembangan kemampuan organisasi masyarakat dalam mendukung pengembangan masyarakat secara lebih luas (Aref et al., 2010).

\section{KESIMPULAN}

Pemberdayaan merupakan bagian dari bentuk pengembangan manusia, yang dilandasi paradigma pembangunan yang berpusat pada manusia (masyarakat), dengan lebih menekankan pada pelibatan partisipasi dan pengembangan secara bottom-up. Pendekatan kolektif dalam pemberdayaan, memberikan ruang terjadinya pemberdayaan secara agregat dan pelibatan individu di dalamnya, dalam pemberdayaan kolektif akan melibatkan pemberdayaan individu. Strategi pemberdayaan dengan pengembangan kapasitas kelembagaan mempermudah dalam pengorganisasian dan pelibatan partisipasi dalam proses pelaksanaan pemberdayaan.

Pengembangan kapasitas kelembagaan mencakup pada pengembangan SDM dan kepemimpinan dalam kelembagaan masyarakat, dan ditopang stimuli dengan bantuan fasilitas. Dampak pemberdayaan melalui pengembangan kapasitas, dengan melibatkan partisipasi anggota poktan dalam setiap kegiatan, mendorong terjadinya perubahan dalam kelembagaan poktan, dan perubahan tersebut dipahami dan disadari oleh anggota poktan sebagai hasil jerih-payah partisipasinya dalam program pemberdayaan. Perubahan penting dari hasil pengembangan kapasitas adalah semakin kuatnya kemampuan masyarakat (dalam hal ini petani anggota poktan) dalam membuat keputusan bersama dan menyelesaikan peramasalahan secara lebih mandiri dalam kebersamaan.

\section{UCAPAN TERIMAKASIH}

Terimakasih disampaikan kepada Direktorat Riset dan Pengabdian Masyarakat (DRPM), Ditjen Risbang, Kemenristek-dikti, atas pembiyaan pelaksanaan pengabdian masyarakat skema PPDM, melalui program hibah kompetitif nasional, tahun anggaran 2018.

\section{REFERENSI}

Adamson, D. (2010). Community empowerment. International Journal of Sociology and Social

Ekonomi, Sosial, dan Budaya

1291 
Policy, $\quad 30(3 / 4), \quad 114-126$. https://doi.org/10.1108/01443331011033319

Adamson, D., \& Bromiley, R. (2013). Community empowerment: learning from practice in community regeneration. International Journal of Public Sector Management, 26(3), 190-202. https://doi.org/10.1108/IJPSM-08-2011-0105

Al-Madadha, A. (2014). Linking an Integrated Approach of. 2(June), 141-146.

Albuquerque, C. P., Santos, C. C., \& Almeida, H. D. S. N. S. (2017). Assessing "empowerment" as social development: goal and process. European Journal of Social Work, 20(1), 88100.

https://doi.org/10.1080/13691457.2016.11860 08

Alkire, S., Meinzen-Dick, R., Peterman, A., Quisumbing, A., Seymour, G., \& Vaz, A. (2013). The Women's Empowerment in Agriculture Index. World Development, 52, 71-91.

https://doi.org/10.1016/j.worlddev.2013.06.00 7

Aref, F., Redzuan, M., \& Gill, S. S. (2010). Dimensions of Community Capacity Building : A review of its Implications in Tourism Development. Journal of America Sciences, 6(1), 172-180.

Bagley, C., \& Ackerley, C. L. (2006). "I am much more than just a mum". Social capital, empowerment and Sure Start. Journal of Education Policy, 21(6), 717-734. https://doi.org/10.1080/02680930600969282

Fitzgerald, M. A. (2011). Combining Constructivist and Empowerment Theories in the Preparation of Educational Leaders. Journal for the Practical Application Aof Constructivist Theory in Education, 5(1), 1-15.

Hadiyanti, P. (2016). A Group Approach in a Community Empowerment: A Case Study of Waste Recycling Group in Jakarta. Journal of Education and Practice, 7(29), 157-167. Retrieved from http://www.iiste.org/Journals/index.php/JEP/ar ticle/view/33611/34804
Hannon, L. (2019). How to empower a community? Helping communities take control of their health destiny. Preventive Medicine Reports, $13(2)$, $166-169$. https://doi.org/10.1016/j.pmedr.2018.12.001

Maani, K. D. (2011). Teori ACTORS dalam Pemberdayaan Masyarakat. Jurnal Demokrasi, $X(1), 53-66$.

Prasetyono, D. W., Astuti, S. J. W., Supriyanto, \& Syahrial, R. (2017). Pemberdayaan Petani Berbasis Modal Sosial dan Kelembagaan. AJIE-Asian Journal of Innovation and Entrepreneurship, 2(3), 231-238. Retrieved from

http://journal.uii.ac.id/ajie/article/viewFile/838 $7 / 7505$

Prasojo, E. (2003). People and Society Empowerment: Perspektif Membangun Partisipasi Publik. Retrieved from http://ekoprasojo.com/wpcontent/uploads/2013/12/PerspektifMembangu nPartisipasi-Publik.pdf

Reininger, B., Martin, D. W., Ross, M., Sinicrope, P. S., \& Dinh-Zarr, T. (2006). Advancing the theory of collective empowerment: A qualitative study. International Quarterly of Community Education, 25(3), 211-238. https://doi.org/10.16953/deusbed.74839

Şahİn, F. (2016). Implications of social constructionism for social work Implications of social constructionism for social work. 5385(June).

https://doi.org/10.1080/21650993.2006.97559 92

Sianipar, C. P. M., Yudoko, G., Adhiutama, A., \& Dowaki, K. (2013). Community Empowerment through Appropriate Technology: Sustaining the Sustainable Development. Procedia Environmental Sciences, 17, 1007-1016. https://doi.org/10.1016/j.proenv.2013.02.120

Suarez-Balcazar, Y., Balcazar, F. E., Taylor-Ritzler, T., \& Iriarte, E. G. (2008). Capacity Building and Empowerment: Gateways: International Journal of Community Research and Engagement, 1(1), 179-196.

$$
\text { Ekonomi, Sosial, dan Budaya }
$$


Zamhariri. (2008). Pengembangan Masyarakat: Islam, 4(1), 101-110.

Perspektif Pemberdayaan dan Pembagunan. Komunitas, Jurnal Pengembangan Masyarakat 